\title{
The oestrous cycle of the ewe after active immunization against prostaglandin F-2 $\alpha$
}

\author{
R. J. Scaramuzzi* and D. T. Baird \\ M.R.C. Unit of Reproductive Biology, Department of Obstetrics and Gynaecology, \\ University of Edinburgh, 39 Chalmers Street, Edinburgh EH3 9ER, U.K.
}

\begin{abstract}
Summary. Six ewes were immunized against a prostaglandin F-2 $\alpha$-protein conjugate. Between 24 and 82 days after immunization the regular cyclic occurrence of oestrus was abolished in all six ewes. Further investigations of the immunized animals revealed that the blockade of oestrus was due to a persistence of the $C L$ and the constantly elevated ( $>2 \mathrm{ng} / \mathrm{ml}$ ) blood levels of progesterone. Surgical enucleation of the persistent $\mathrm{CL}$ was promptly followed by a fall in progesterone concentrations $(<0.5 \mathrm{ng} / \mathrm{ml})$, normal oestrus and a subsequent return to a state of constantly elevated blood progesterone levels.

These results show that neutralization of the biological activity of PGF by active immunization against PGF-2 $\alpha$ results in a failure of luteal regression and provide evidence that endogenous PGF is involved in normal luteal regression in this species.
\end{abstract}

\section{Introduction}

The early studies of Moor \& Rowson $(1964,1966 \mathrm{a}, \mathrm{b})$ established that a clear relationship existed between the uterus and the CL of the ewe. The exact nature of this relationship became a highly controversial issue (Nalbandov \& Cook, 1968) and is still not completely resolved. Much of the available evidence supports the claim that luteal regression is caused by the local vascular transfer of uterine prostaglandin F-2 $\alpha$ (PGF-2 $\alpha$ ) from the uterine vein to the ovarian artery (Del Campo \& Ginther, 1973; McCracken et al., 1973b; Goding, 1974). However, several authors have published results which challenge this hypothesis (Nalbandov, 1973; Coudert et al., 1974a, b). Although a very strong case can be presented for PGF-2 $\alpha$ as the uterine luteolytic compound, the evidence is mostly circumstantial and the controversy persists, partly because of the lack of experimental results directly implicating endogenous uterine PGF-2 $\alpha$.

In the present experiments, the biological activity of endogenous PGF-2 $\alpha$ was neutralized by active immunization against PGF-2 $\alpha$-protein conjugates in an attempt to examine any causal relationship between endogenous PGF-2 $\alpha$ and luteal function in the ewe. Some of the results have been published in abstract form (Scaramuzzi et al., 1973).

\section{Materials and Methods}

\section{Immunization protocols}

Eleven mature Welsh Mountain ewes were randomly allocated to two groups. The six animals in the first group were immunized against PGF-2 $\alpha$-protein conjugates and the remaining five animals formed a control group. Prostaglandin F-2 $\alpha$ covalently linked to either bovine serum albumen (PGF-2 $\alpha-B S A)$ or to keyhole limpet haemocyanin (PGF-2 $\alpha-\mathrm{KLH}$ ) was used as the immunogen (Stylos et al., 1972). Three to four $\mathrm{mg}$ of either conjugate was dissolved in $2 \mathrm{ml}$ physiological saline and emulsified with an equal volume of Freund's complete adjuvant (Difco Laboratories, Detroit). The emulsion was immediately given by subcutaneous injection at eight sites $(0 \cdot 5$ $\mathrm{ml} / \mathrm{site}$; total dose $4 \mathrm{ml}$ containing 3-4 mg conjugate). At the same time, the animals were given

* Present address : C.S.I.R.O. Division of Animal Physiology, P.O. Box 239, New South Wales 2148, Australia. 
an intramuscular injection of $0.5 \mathrm{ml}$ Pertussis vaccine (Batch no. 80938: Burroughs Wellcome, Beckenham, Kent) as an additional adjuvant, and $500 \mathrm{ml}$ blood were withdrawn from the jugular vein by venepuncture. The control animals were treated in a similar manner but with an emulsion of saline and Freund's complete adjuvant. The primary immunization was given in October 1972 and an identical booster immunization using $2 \mathrm{mg}$ PGF-2 $\alpha$-BSA per animal was given to all sheep in January 1973,91 days after the primary immunization.

\section{Detection of oestrus}

The oestrous cycles of all eleven ewes were synchronized by the use of Cronolone (G. D. Searle \& Co., High Wycombe, Bucks.) pessaries (Robinson, 1967). The primary immunizations were then given between Days 4 and 8 of the second oestrous cycle after sponge withdrawal. Oestrus was detected by vasectomized rams fitted with harnesses and marking crayons (Radford et al., 1960).

\section{Progesterone analysis}

Blood for progesterone assay was taken by jugular venepuncture into heparinized 10-ml tubes. The plasma was removed after centrifugation and stored at $-20^{\circ} \mathrm{C}$ until assay. Progesterone was determined by the radioimmunoassay procedure described in detail by Scaramuzzi et al. (1975). Blood samples were taken daily, commencing 35 days after primary immunization and continuing for 52 days in the control ewes and for 72 days in the others.

\section{Antiserum titre and specificity}

Samples of blood (100-300 ml) were taken by jugular venepuncture $28,49,63$ and 91 days after the primary immunization and 7,14 and 21 days after the booster immunization. The serum was removed $24 \mathrm{hr}$ later and stored at $-20^{\circ} \mathrm{C}$. The titre and specificity of the antisera were determined with the methods described for steroid antisera (Scaramuzzi et al., 1975). Tritiated prostaglandin F-1 $\alpha$ ([5,6- $\left.{ }^{3} \mathrm{H}\right]$ PGF-1 $\alpha$; sp. act. $53 \mathrm{Ci} / \mathrm{mmol}$ : Radiochemical Centre, Amersham) was preferred to labelled PGF-2 $\alpha$ because of its higher specific activity and was used as the tracer in all determinations of titre and specificity (Caldwell et al., 1971). Separation of the bound and free fractions was conducted as described for steroid hormones (Scaramuzzi et al., 1975): the most efficient separation of the bound and free fractions required $5.0 \mathrm{mg}$ charcoal $/ \mathrm{ml}$ and $0.25 \mathrm{mg}$ dextran $/ \mathrm{ml}$.

\section{Prostaglandin analysis}

The concentration of PGF-2 $\alpha$ in the samples of antiserum were determined by gas-liquid chromatography/mass spectrometry (Kelly, 1973).

\section{Results}

\section{Antiserum titres}

The changes in antiserum titre in individual ewes after the primary immunization are shown in Text-fig. 1. The range of titres observed in response to immunization with either conjugate was very large. The mean antiserum titre increased linearly to 49 days after primary immunization, and remained at that level until the booster immunization at 91 days after which the titre increased rapidly to reach a maximum 14 to 21 days later (Text-fig. 2).

\section{Prostaglandin F-2 $\alpha$ levels}

The concentrations of PGF-2 $\alpha$ in jugular venous serum are also illustrated in Text-fig. 2. The peripheral concentration of PGF-2 $\alpha$ increased in a pattern closely resembling the pattern of increase 


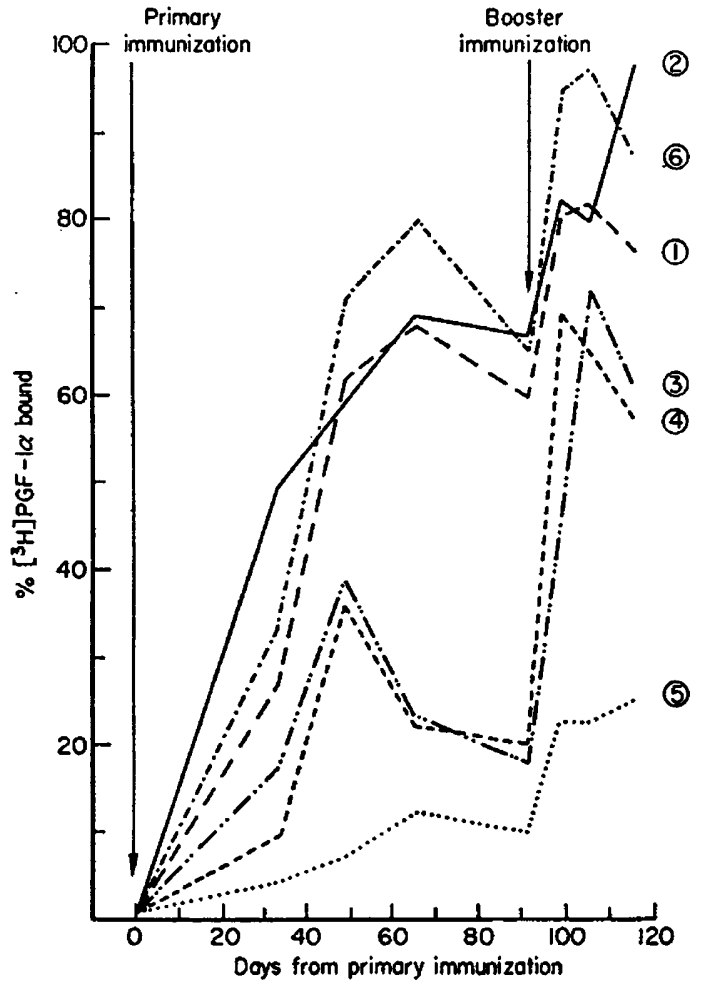

Text-fig. 1. The change in the proportion of $\left[5,6-{ }^{3} \mathrm{H}\right] \mathrm{PGF}-1 \alpha$ bound to a $1 / 100$ dilution of serum taken from Ewes 1, 2 and 5 after primary immunization against PGF-2 $\alpha$-BSA and Ewes 3,4 and 6 after primary immunization against PGF-2 $\alpha-K L H$. Booster immunization was effected with PGF-2a-BSA 91 days after primary immunization. Each point is the mean of a determination carried out in triplicate.

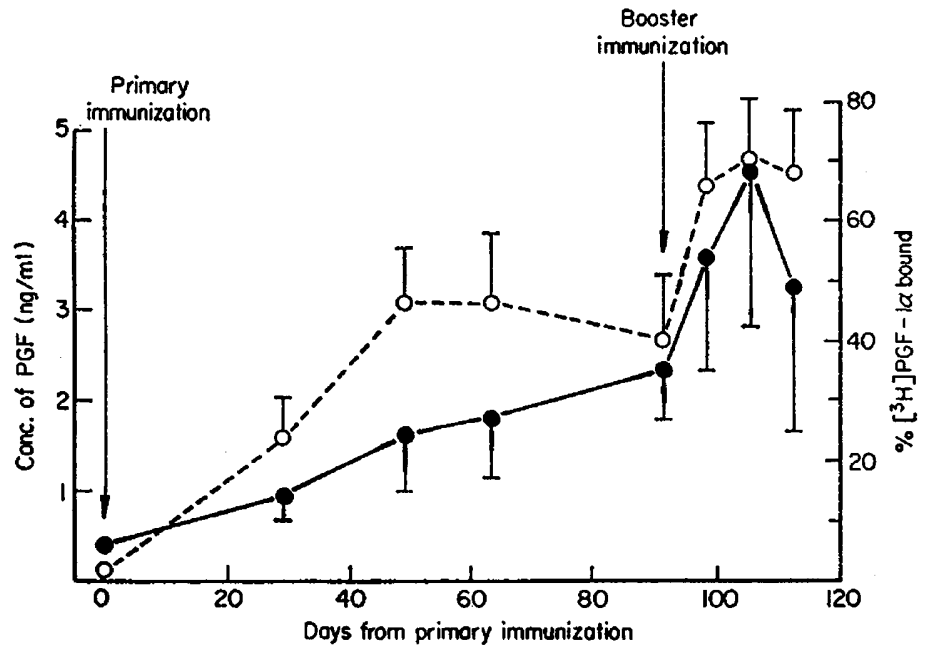

Text-fig. 2. The change in the proportion of $\left[5,6-{ }^{3} \mathrm{H}\right] \mathrm{PGF}-1 \alpha$ bound to a $1 / 100$ dilution of serum ( $(\bullet)$ and the concentration of PGF-2 $\alpha$ in the same serum samples $(O)$ from six ewes immunized against PGF-2 $\alpha$-protein conjugates. Values are means \pm S.E.M. 
in antiserum titre, and the peripheral concentration of PGF-2 $\alpha$ was significantly correlated with the antiserum titre $(r=0.68, n=42, P<0.05)$.

\section{Oestrous cycles}

A record of the oestrous cycles of the eleven ewes is shown in Text-fig. 3. Four of the six immunized ewes failed to show natural oestrus at the expected time 24-26 days after the primary immunization and at any subsequent time. The other two ewes continued to experience regular oestrous cycles until 82 days after immunization when they too failed to show oestrus at the expected time. Following surgical enucleation of all CL 64 days after primary immunization, all six ewes were in oestrus within 3 days and were mated to fertile rams. None became pregnant, and none showed oestrus in the subsequent 90 days, by which time ewes of this breed had become seasonally anoestrous (see Text-fig. 3).

(a)
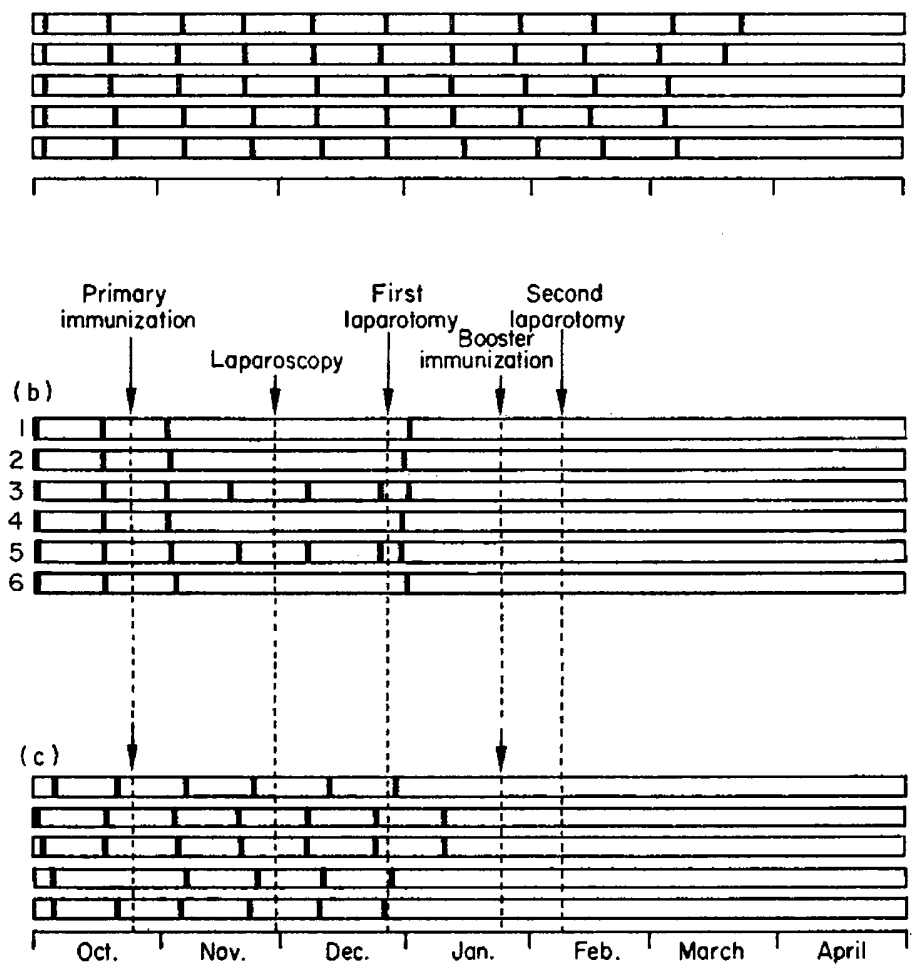

Text-fig. 3. The oestrous cycle records'of Welsh Mountain'ewes immunized against PGF-2 $\alpha$-protein conjugates. (a) Five control ewes; (b) six ewes immunized against PGF-2 $\alpha$-protein conjugates; (c) five control ewes immunized with Freund's complete adjuvant. These five animals became pregnant in January 1973. Each black bar indicates the day of oestrus at the onset of a new oestrous cycle. The immunized ewes are identified by the numbers shown on the left. The CL were marked at the laparoscopy and enucleated at the first laparotomy.

In the periods before and immediately after immunization, the six immunized animals had 18 oestrous cycles with a mean length $( \pm$ S.E.) of $16 \cdot 8 \pm 0 \cdot 2$ days. The five control animals showed 26 regular oestrous cycles $(16 \cdot 8 \pm 0 \cdot 1$ days) from October until January when they were mated to intact rams and became pregnant. Data for an additional group of five ewes of the same breed and kept in the same flock are also illustrated in Text-fig. 3. The breeding season extended from October to midMarch in this particular year, the mean length of 47 oestrous cycles being $17 \cdot 1 \pm 0 \cdot 1$ days. 


\section{Morphological observations}

These are summarized in Table 1. Laparoscopy was carried out 36 days after primary immunization and at least one CL was present in the ovaries of each of the six ewes. An attempt was made to mark CL with carbon black using a 6-in. spinal needle introduced into the abdomen. At laparotomy 28 days later (64 days after primary immunization), 3/4 ewes (Nos 1, 2 and 4) that were acyclic had persistent CL. Ewe 6 had two unmarked CL present in the left ovary (Table 1). The two animals (Ewes 3 and 5) which were still showing regular oestrous cycles had old corpora albicantia and new CL present in their ovaries (Table 1). At this time, all CL were surgically enucleated and fixed in aqueous Bouin for subsequent histological examination. A second laparotomy $\mathbf{4 2}$ days after enucleation revealed that all the ewes had morphologically normal CL although none had shown any subsequent oestrous behaviour and none was pregnant.

The histological appearance of a CL taken from Ewe 255 days after her last recorded oestrus is shown in Plate 1. The CL appears structurally normal with the lutein cells having a well developed granular cytoplasm. The progesterone concentration in this animal immediately before induction of anaesthesia and enucleation of the CL was $5 \cdot 0 \mathrm{ng} / \mathrm{ml}$.

Table 1. Observations of the CL present in the ovaries of six ewes immunized against PGF-2 $\alpha$-protein conjugates

\begin{tabular}{|c|c|c|c|c|c|c|}
\hline \multirow[b]{3}{*}{ No. } & \multicolumn{6}{|c|}{ No. of CL present at: } \\
\hline & \multicolumn{2}{|c|}{ Laparoscopy* } & \multicolumn{2}{|c|}{ First laparotomy† } & \multicolumn{2}{|c|}{ Second laparotomy } \\
\hline & LO & RO & LO & RO & LO & RO \\
\hline 1 & 0 & 1 & $\mathbf{0}$ & $\begin{array}{c}1 \\
\text { (persistent) }\end{array}$ & 1 & $\mathbf{0}$ \\
\hline 2 & 2 & 0 & $\begin{array}{c}2 \\
\text { (persistent) }\end{array}$ & 0 & 1 & 0 \\
\hline 3 & $\mathbf{0}$ & 1 & $\begin{array}{c}1 \\
(\mathrm{CA})\end{array}$ & $\begin{array}{c}1 \\
\text { (new) }\end{array}$ & 1 & 0 \\
\hline 4 & 1 & 0 & $\begin{array}{c}1 \\
\text { (persistent) }\end{array}$ & 0 & 1 & 0 \\
\hline 5 & 1 & 0 & $\begin{array}{c}1 \\
\text { (new) }\end{array}$ & $\begin{array}{c}1 \\
(\mathrm{CA})\end{array}$ & 0 & 1 \\
\hline 6 & 1 & 1 & 2 & 0 & 0 & 2 \\
\hline Totals & 5 & 3 & 6 & 2 & 4 & 3 \\
\hline
\end{tabular}

LO, left ovary; RO, right ovary; CA, corpus albicans.

* At 36 days after primary immunization: all the $\mathrm{Cl}$ were marked with India ink.

$\dagger$ At 64 days after primary immunization: all CL were surgically enucleated.

$¥$ At 44 days after surgical enucleation of CL (108 days after primary immunization).

\section{Progesterone concentration}

The concentrations of progesterone in jugular venous plasma of all the ewes is illustrated in Text-fig. 4. The mean $( \pm$ S.E.) concentration for the control animals rose steadily from the periovulatory nadir of $0 \cdot 4 \pm 0 \cdot 1 \mathrm{ng} / \mathrm{ml}$ on Day 1 to peak values greater than $4 \mathrm{ng} / \mathrm{ml}$ on Days 12 and 13 of the oestrous cycle $(4 \cdot 1 \pm 0 \cdot 5$ and $4 \cdot 2 \pm 0 \cdot 4 \mathrm{ng} / \mathrm{ml}$ respectively). Ewes $1,2,4$ and 6 had concentrations of progesterone that remained above $2 \mathrm{ng} / \mathrm{ml}$ for the 30 days of sampling before enucleation of the $\mathrm{CL}$, although individual values fluctuated widely. Ewes 3 and 5 had normal ovulatory cycles, and their patterns of progesterone concentration closely resembled those seen in the control animals. Following enucleation of the CL, the progesterone concentrations dropped to values of less than $0.5 \mathrm{ng} / \mathrm{ml}$ in all six immunized animals. The pattern of progesterone concentration for 44 days following enucleation of the $C L$ is shown in Text-fig. 5. The progesterone concentration rose steadily to reach a plateau at about $4 \mathrm{ng} / \mathrm{ml} 12$ days after oestrus, and remained at about this level for the duration of the sampling period ( 40 days after oestrus). 


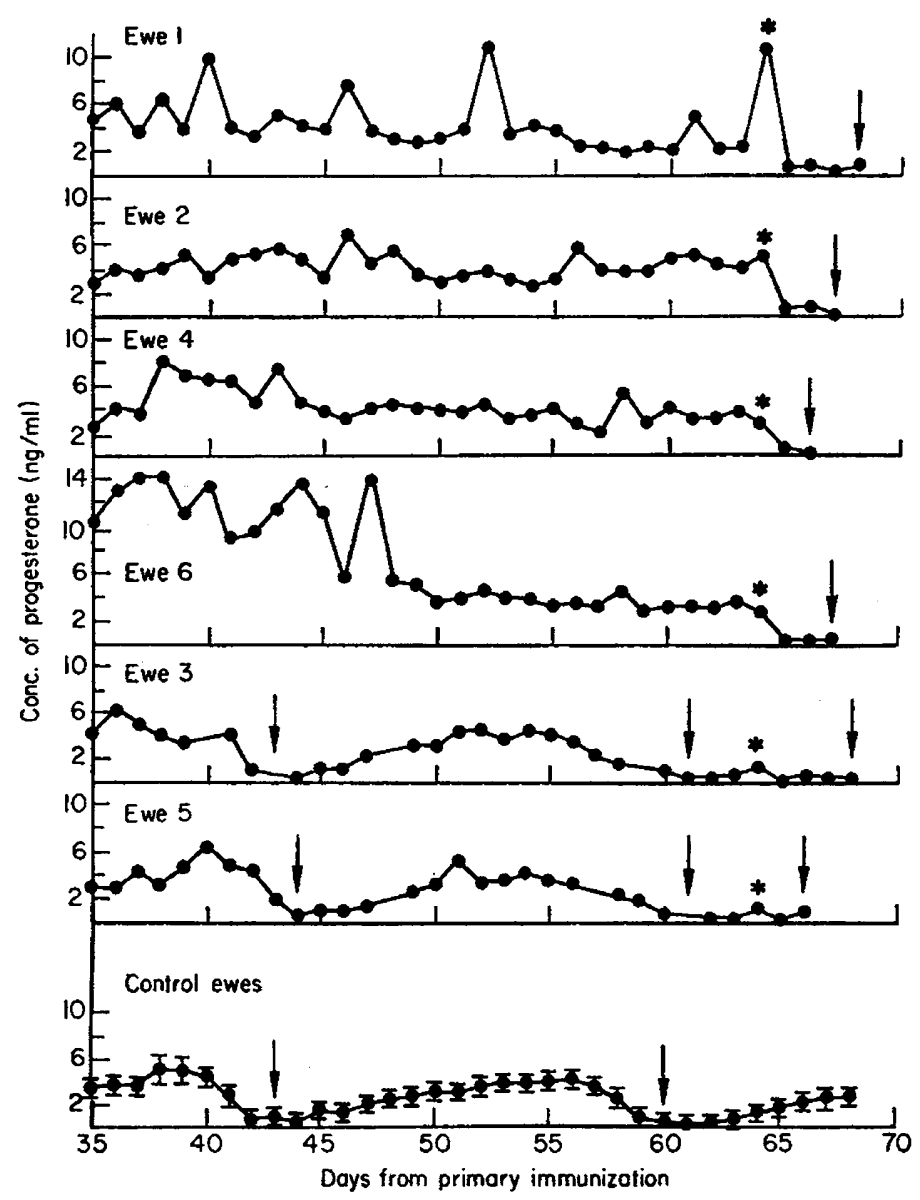

Text-fig. 4. The concentration of progesterone in jugular venous plasma of Welsh Mountain ewes immunized against PGF-2 $\alpha$-protein conjugates. The individual patterns are shown for the six immunized ewes and the means \pm S.E.M. are shown for the control ewes. The arrows indicate days of oestrus, and the asterisks indicate the day of surgical enucleation of the $C L$ in the six immunized ewes.

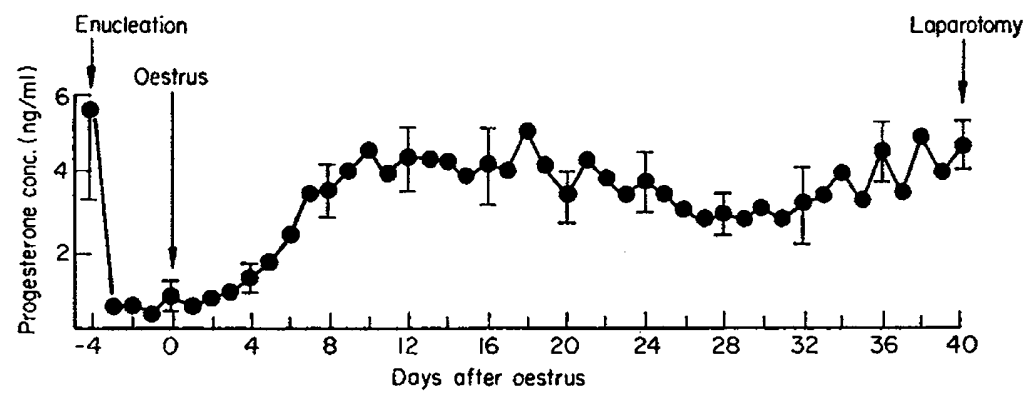

Text-fig. 5. Concentrations of progesterone in jugular venous plasma following surgical enucleation of the CL in six Welsh Mountain ewes immunized against PGF- $2 \alpha$-protein conjugates. Values are means \pm S.E.M.

\section{Specificity}

The specificities of six antisera from four of the immunized ewes are shown in Table 2. The remaining 36 antisera were not tested. The antisera tested showed a marked degree of specificity 
PLATE 1

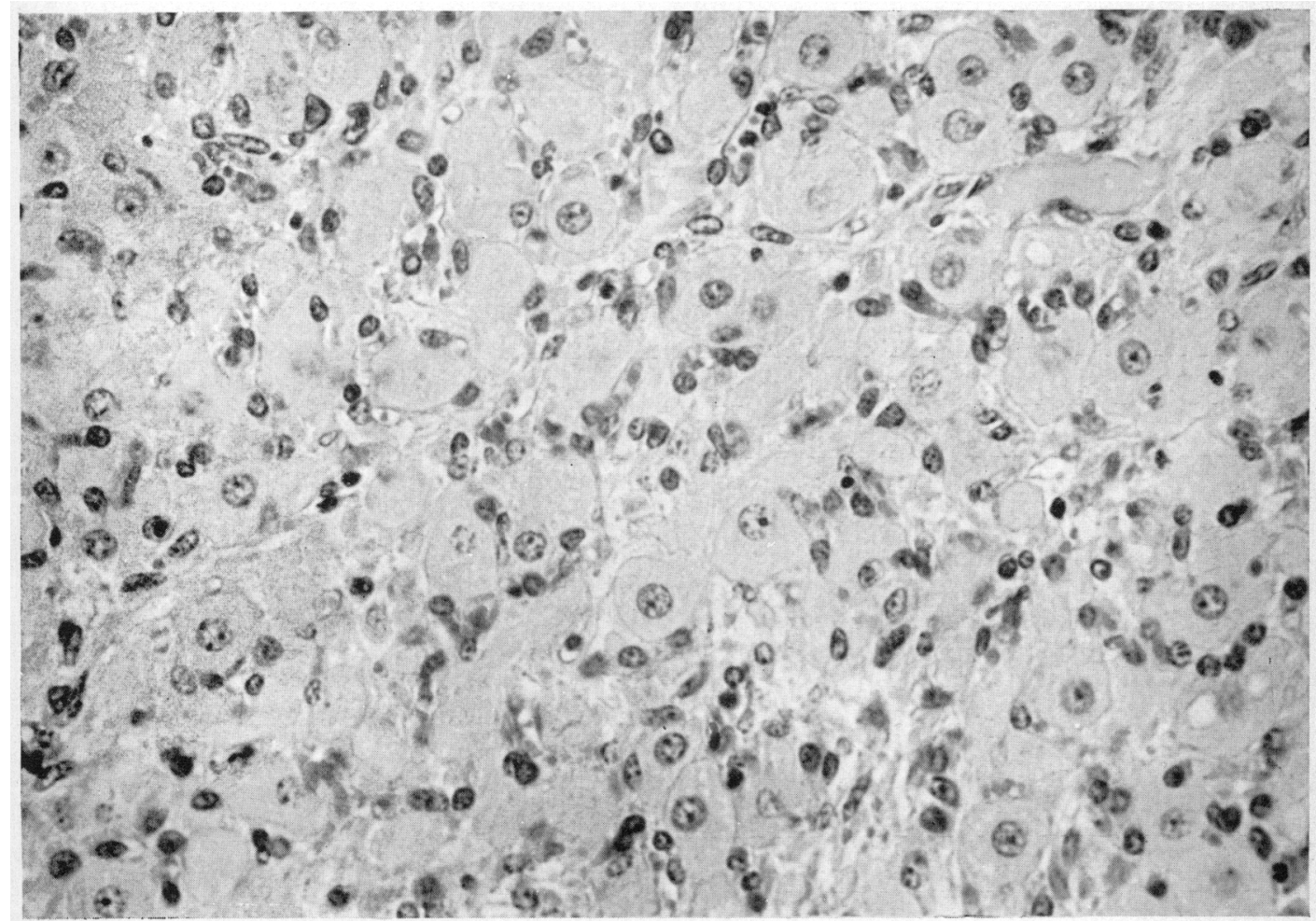

The corpus luteum of a ewe removed 55 days after the last recorded oestrus and 64 days after primary immunization against a PGF-2 $\alpha$-protein conjugate. $\times 440$. 
towards PGF-1 $\alpha$ and PGF-2 $\alpha$. Two of the animals (Ewes 1 and 2) produced antisera with some cross-reactivity towards PGE-1 and PGE-2, but there was little cross-reactivity against any other prostaglandins.

Table 2. The specificity of the antisera to prostaglandin F-2 $\alpha$

\begin{tabular}{|c|c|c|c|c|c|c|}
\hline Compound tested & $\begin{array}{c}\text { Ewe } 1 \text { at } 21 \\
\text { days* } \\
(1 / 2000)\end{array}$ & $\begin{array}{c}\text { Ewe } 2 \text { at } 21 \\
\text { days* } \\
(1 / 2000)\end{array}$ & $\begin{array}{c}\text { Ewe } 4 \text { at } 21 \\
\text { days* } \\
(1 / 800)\end{array}$ & $\begin{array}{c}\text { Ewe } 6 \text { at } 7 \\
\text { days* } \\
(1 / 10,000)\end{array}$ & $\begin{array}{c}\text { Ewe } 6 \text { at } 14 \\
\text { days* } \\
(1 / 15,000)\end{array}$ & $\begin{array}{c}\text { Ewe } 6 \text { at } 21 \\
\text { days* } \\
(1 / 25,000)\end{array}$ \\
\hline PGF-2 $\alpha$ & 100 & 100 & 100 & 100 & 100 & 100 \\
\hline PGF-1 $\alpha$ & 127 & 154 & 52 & 275 & 197 & 226 \\
\hline PGF-3 $\alpha$ & - & - & - & - & 0.25 & - \\
\hline PGF-2 $\beta$ & 6 & 1.67 & $0 \cdot 36$ & 0.16 & 0.15 & 0.12 \\
\hline $\begin{array}{l}\text { 15-Oxo-PGF- } \alpha \\
\text { 13,14-Dihydro-15-oxo- }\end{array}$ & 一 & $<0 \cdot 1$ & $<0 \cdot 1$ & $1 \cdot 00$ & $0 \cdot 17$ & $0 \cdot 18$ \\
\hline PGF-2 $\alpha$ & - & 一 & - & 一 & $<0.1$ & - \\
\hline 15-Methyl-PGF-2 $\alpha$ & - & - & - & - & 11 & - \\
\hline PGE-1 & 80 & 29 & 0.51 & 0.92 & 0.33 & 0.50 \\
\hline PGE-2 & 71 & 16 & $0 \cdot 11$ & $0 \cdot 28$ & $0 \cdot 13$ & 0.14 \\
\hline PGA-1 & 0.46 & 0.14 & $<0.1$ & $<0.1$ & $<0.1$ & 0.11 \\
\hline PGB-1 & $<0 \cdot 1$ & $<0.1$ & $<0 \cdot 1$ & $<0 \cdot 1$ & $<0 \cdot 1$ & $<0.1$ \\
\hline
\end{tabular}

The specificity is expressed as the $\%$ cross-reactivity measured at $50 \%$ displacement (Thorneycroft et al., 1970) and is expressed relative to PGF-2 $\alpha$.

* After booster immunization; figures in parentheses are initial dilutions.

\section{Discussion}

The results of the present experiments show that four out of six ewes immunized against PGF-2 $\alpha-$ protein conjugates rapidly became acyclic and that their failure to show regular oestrous cycles is due to a persistence of the CL. The CL that persist are functionally normal in that they secrete progesterone in normal or above normal quantities (Text-fig. 4) and they are morphologically indistinguishable from normal CL (Plate 1). Similar results have recently been reported for the guineapig (Horton \& Poyser, 1974). When the CL of the ewes were surgically enucleated, normal oestrus and presumably ovulation followed within 2-3 days; the newly formed CL persisted. The two animals (Ewes 3 and 5) that continued to show regular oestrous cycles up to the time of surgical enucleation of the CL had lower titres to PGF than the four acyclic animals (Text-figs 1,3 and 5). This relationship between titre of antibody to PGF and persistence of the CL was qualitative rather than quantitative. The persistence of the CL could be due to neutralization of the biological activity of a uterine luteolysin or the stimulation of a pituitary luteotrophic complex. Karsch et al. (1970) have shown that luteal maintenance can be achieved by overcoming the normal lytic stimulus with large doses of pituitary gonadotrophins. This is unlikely to be an explanation for our observations, however, because the concentration of LH was measured in a few plasma samples from the immunized ewes and was within the normal range (R. J. Scaramuzzi \& D. T. Baird, unpublished results).

The specificity of a selected number of antisera show that the only compounds capable of binding to each of the antisera tested were PGF-1 $\alpha$ and PGF-2 $\alpha$. Most other compounds did not show crossreactivity to any of the antisera tested while PGE-1 and PGE-2 had significant cross-reactivity with only $2 / 6$ antisera tested. Since PGF- $1 \alpha$ and PGF- $2 \alpha$ were the only two compounds having a high affinity for all the antisera tested, it can be concluded that the persistence of the CL observed in these experiments was due to the inactivation of the biological activity of PGF-1 $\alpha$ and PGF- $2 \alpha$. Of these two prostaglandins only PGF-2 $\alpha$ is found in the endometrium of the ewe in any appreciable quantity (Wilson et al., 1972). The immunoglobulins to which the endogenous prostaglandin is bound are large molecules (mol. wt of IgG is 150,000 ) and probably cannot cross the cell membrane. The biological inactivation of PGF would thus be confined to PGF present in the extracellular 
compartments of blood plasma and lymph. These results are compatible with the much debated countercurrent mechanism of luteolysis (McCracken et al., 1972).

The rapid increase in anti-prostaglandin titre seen following primary immunization is comparable to changes in anti-steroid titres seen after immunization against steroids (Scaramuzzi et al., 1975), although the response appears more variable with the prostaglandin conjugates. There appeared to be no difference in response to the two conjugates used for immunization. Despite the poor response in two of the ewes, the amount of anti-prostaglandin produced was sufficient to neutralize PGF-2 $\alpha$ and so prevent normal luteolysis. Ewes 1,2, 4 and 6 failed to show oestrus approximately 30 days after primary immunization when the titres of anti-PGF were very low (as low as $15 \%$ binding at 1/100 for Ewe 4; Text-fig. 1); all of the antisera obtained at this time were unsuitable for use in radioimmunoassays for PGF.

The changes in antiserum titre were closely paralleled by changes in the total (bound + free) circulating PGF-2 $\alpha$ (Text-fig. 2) and a significant correlation between the two was noted. The prostaglandin is mostly antibody bound, and so is biologically inactive and protected against the normal rapid metabolic breakdown (Piper et al., 1970). The equilibrium constant (K) of most antibodyantigen reactions is far to the right, and $>99 \%$ of the circulating PGF- $2 \alpha$ would be expected to be antibody bound; this is so for steroid antisera in vivo (Hillier et al., 1973) and there is no reason to expect antisera to PGF to behave differently.

Under these conditions, elevated blood levels of PGF-2 $\alpha$ similar to those seen in rabbits immunized against testosterone (Thorneycroft et al., 1975) would be expected. The concentration of total circulating PGF- $2 \alpha$ following immunization was so high that artifacts produced by measuring PGF-2 $\alpha$ in serum rather than plasma (Silver et al., 1972) are insignificant. Most of the pre-immunization samples were at the detection limit of the method.

These experiments lead us to conclude that endogenous PGF is involved in the mechanism of luteolysis in the sheep. Taken in conjunction with the vast body of evidence showing that exogenous PGF-2 $\alpha$ can induce luteolysis (Del Campo \& Ginther, 1973; McCracken et al., 1973a, b; Goding, 1974) they show beyond all reasonable doubt that PGF- $2 \alpha$ is the luteolytic hormone in sheep.

We wish to acknowledge Dr R. B. Land and Mr A. G. Wheeler for help in collecting daily blood samples over 72 consecutive days, and Dr R. W. Kelly for performing the determination of PGF-2 $\alpha$ concentration. The technical help of Mr W. G. Davidson, Mrs G. Young and Mrs S. Henderson is gratefully acknowledged. The prostaglandins were a gift from Dr J. E. Pike of the Upjohn Company, Kalamazoo, Michigan, U.S.A., and the prostaglandin-protein conjugates were a gift from Dr W. Stylos of the Worcester Foundation for Experimental Biology, Shrewsbury, Massachusetts, U.S.A.

\section{References}

Caldwell, B.V., Burstein, S., Brock, W.A. \& SperofF, L. (1971) Radioimmunoassay of the F prostaglandins. J. clin. Endocr. Metab. 33, 171-175.

Coudert, S.P., Phillips, G.D., Faiman, C., CherNeCKI, W. \& Palmer, M. (1974a) A study of the utero-ovarian circulation in sheep with reference to local transfer between venous and arterial blood. J. Reprod. Fert. 36, 319-331.

Coudert, S.P., Phillips, G.D., Faiman, C., CherNECKI, W. \& PALMER, M. (1974b) Infusion of tritiated prostaglandin $F_{2 \alpha}$ into the anterior uterine vein of the ewe: absence of local venous-arterial transfer. J. Reprod. Fert. 36, 333-343.

Del CAMPo, C.H. \& Ginther, O.J. (1973) Vascular anatomy of the uterus and ovaries and the unilateral luteolytic effect of the uterus: horses, sheep and swine. Am. J. vet. Res. 34, 305-316.
Goding, J.R. (1974) The demonstration that $\mathrm{PGF}_{2 \alpha}$ is the uterine luteolysin in the ewe. J. Reprod. Fert. 38, 261-272.

Hillier, S.G., Cole, E.N., Groom, G.V., Boyns, A.R. \& Cameron, E.H.D. (1973) Effect of active immunization against testosterone-3-BSA on circulating levels of testosterone, $\mathrm{LH}$, prolactin and testosterone antibody titre in the male rat. Steroids 22, 227-238.

Horton, E.W. \& Poyser, N.L. (1974) Elongation of oestrous cycle in the guinea pig following active immunization against prostaglandin $\mathrm{F}_{2 \alpha}$. Prostaglandins 5, 349-354.

Karsch, F.J., Noveroske, J.W., Roche, J.F., Norton, H.W. \& Nalbandov, A.V. (1970) Maintenance of ovine corpora lutea in the absence of ovarian follicles. Endocrinology 87, 1228-1236. 
KELLY, R.W. (1973) Method for the measurement of prostaglandin $\mathrm{F}_{2 \alpha}$ in biological fluids by gas chromatography-mass spectrometry. Analyt. Chem. 45, 2079-2082.

McCracken, J.A., Carlson, J.C., Glew, M.E., Goding, J.R., BaIRD, D.T., Gréen, K. \& SAMuelssoN, B. (1972) Prostaglandin $F_{2 \alpha}$ identified as a luteolytic hormone in sheep. Nature, New Biol. 238, 129-134.

McCracken, J.A., Baird, D.T., CARlson, J.C., GodING, J.R. \& BARCikowski, B. (1973a) The rôle of prostaglandins in luteal regression. J. Reprod. Fert., Suppl. 18, 133-142.

McCracken, J.A., Barcikowski, B., Carlson, J.C., Gréen, K. \& SAmuelsson, B. (1973b) The physiological rôle of prostaglandin $F_{2 \alpha}$ in corpus luteum regression. Adv. Biosci. 9, 599-624.

Moor, R.M. \& Rowson, L.E.A. (1964) Influence of the embryo and uterus on luteal function in the sheep. Nature, Lond. 210, 522-523.

Moor, R.M. \& Rowson, L.E.A. (1966a) Local uterine mechanisms affecting luteal function in the sheep. J. Reprod. Fert. 11, 307-310.

Moor, R.M. \& Rowson, L.E.A. (1966b) The corpus luteum of the sheep: functional relationship between the embryo and the corpus luteum. J. Endocr. 34, 233-239.

Nalbandov, A.V. (1973) Control of luteal function in mammals. In Handbook of Physiology, Section 7: Endocrinology, Vol. II, Female Reproductive System, part 1, pp. 153-167. Eds R. O. Greep \& E. B. Astwood. American Physiological Society, Washington, D.C.

Nalbandov, A.V. \& Cook, B. (1968) Reproduction. A. Rev. Physiol. 30, 245-278.
Piper, P.J., VANe, J.R. \& Wyllie, J.H. (1970) Inactivation of prostaglandins by the lungs. Nature, Lond. 225, 600-604.

RADFORD, H.M., WATSON, R.H. \& Wood, G.F (1960) A crayon and associated harness for the detection of mating under field conditions. Aust. vet. J. 36, 57-66.

Robinson, T.J. (1967) The Control of the Ovarian Cycle in the Sheep. Sydney University Press, Sydney.

Scaramuzzi, R.J., Baird, D.T., Wheeler, A.G. \& LAND, R.B. (1973) The oestrous cycle of the ewe following active immunization against prostaglandin $F_{2 x}$. Acta endocr., Copenh. 177, 318.

Scaramuzzi, R.J., Corker, C.S., Young, G. \& Baird, D.T. (1975) Production of antisera to steroid hormones in sheep. In Steroid Immunoassay, pp. 111-122. Eds E. H. D. Camerson, S. G. Hillier \& K. Griffiths. Alpha Omega Alpha, Cardiff.

Silver, M.J., SMITH, J.B., INGERMAN, C. \& Kocsis, J.J. (1972) The collection and handling of biological samples for prostaglandin analysis. Prostaglandins 2, 75-77.

Stylos, W.A., Burstein, S., Rivetz, B., Gunzalus, P. \& SKarnes, R. (1972) The production of anti-Fprostaglandin serum and its use in radioimmunoassay. Intrasci. chem. Rep. No. 6,

Thorneycroft, I.H., ThORNEYCROFT, N.K., SCARAMUZZI, R.J. \& BLAKE, C.A. (1975) Radioimmunoassay of serum $\mathbf{L H}$ and testosterone in male rabbits actively immunized against testosterone. Endocrinology 97, 301-306.

Wilson, L., JR, Cenedella, R.J., Butcher, R.L. \& INSKEEP, E.K. (1972) Levels of prostaglandins in the uterine endometrium during the ovine estrous cycle. J. Anim. Sci. 34, 93-99.

Received 17 February 1975 